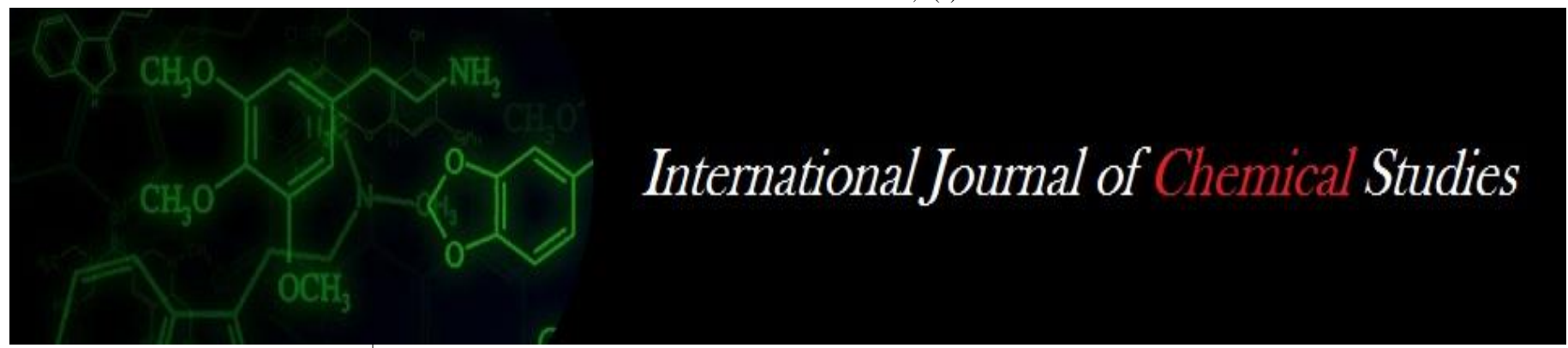

P-ISSN: 2349-8528

E-ISSN: 2321-4902

www.chemijournal.com

IJCS 2020; 8(4): 3205-3208

(C) 2020 IJCS

Received: 04-05-2020

Accepted: 06-06-2020

Navreet Kaur Rai

Department of Genetics and

Plant Breeding, College of

Agriculture, SKRAU, Bikaner,

Rajasthan, India

AK Sharma

Department of Genetics and

Plant Breeding, College of

Agriculture, SKRAU, Bikaner,

Rajasthan, India

Corresponding Author:

Navreet Kaur Rai

Department of Genetics and

Plant Breeding, College of

Agriculture, SKRAU, Bikaner,

Rajasthan, India

\section{Variability and interrelation analysis in cowpea [Vigna unguiculata (L.) Walp.] Genotypes}

\author{
Navreet Kaur Rai and AK Sharma
}

DOI: $\underline{\text { https://doi.org/10.22271/chemi.2020.v8.i4an.10146 }}$

\begin{abstract}
The current experimental trial was conducted to draw out the informations on different variability parameters, correlation and path coefficient for 12 attributes in thirty cowpea genotypes. Analysis of variance showed appreciable and significant genetic variability among the genotypes for all the traits under present study. Phenotypic and genotypic coefficient of variation along with heritability and genetic advance as per cent of mean (genetic gain) were reported high for traits like number of pods per plant, harvest index, seed yield per plant and plant height. Plant height, number of pods per plant, harvest index and number of seeds per pod were significantly and positively associated with seed yield and also contributed directly towards seed yield.
\end{abstract}

Keywords: Variability, correlation, path analysis

\section{Introduction}

Cowpea remains an essential part of subsistence and sustainable production system due to its capacity to restore soil fertility. This crop is very well known for its protein rich values in seeds which ranges from 20 to 25 per cent which is twice of the protein found in most of the cereal crops (Stanton, 1966) ${ }^{[21]}$. In India, this crop has a lot of scope for creating considerable diversity by identifying genotypes which are superior among the existing germplasm and this can be a good strategy to initiate any breeding programme and also for amplifying the productivity and production of cowpea (Singh et al., 2018) ${ }^{[19]}$. Thus, to bridge the existing gaps in cowpea breeding an experiment was conducted at the agriculture research farm of College of Agriculture, Bikaner during kharif season-2019 to rule out the variability, correlation and path coefficient in thirty genotypes of cowpea.

\section{Materials and Methods}

The experimental material for the present investigation consisted of 30 genotypes of cowpea. These genotypes were evaluated in a randomized block design (RBD) with three replications during kharif 2019 at Agriculture Research Farm, College of Agriculture, Bikaner. Each genotype was sown in a double row plot of 4 meter length. The row to row distance and plant to plant distance were kept at $30 \mathrm{~cm}$ and $10 \mathrm{~cm}$, respectively. The coefficient of variation (Burton, 1952) ${ }^{[3]}$, correlation (Searle, 1961) ${ }^{[18]}$ and path coefficient analysis (Wright, 1921) ${ }^{[27]}$ were estimated according to the established statistical procedures.

\section{Result and Discussion}

Analysis of variance revealed wide range of variation and significant differences among all genotypes studied for all the traits, which indicated that the material used had considerable genetic variability (Table 1).Similar finding were reported by Animasaum et al. (2015) ${ }^{[2]}$, Surpura et al. (2017) ${ }^{[23]}$, Patel et al. (2018) ${ }^{[14]}$ and Gupta et al. (2019) ${ }^{[6]}$. Highest PCV and GCV estimates were reported for number of pods per plant $(50.76 \%, 50.05 \%)$, harvest index $(43.05 \%, 42.54 \%)$, seed yield per plant $(41.13 \%, 40.40 \%)$ and plant height $(34.35 \%, 34.30 \%)$ indicating the scope of exploiting variability for further improvement of such characters. Similar results were shown by Surpura et al. (2017) ${ }^{[23]}$ for high PCV and GCV of number of pods per plant, plant height and seed yield per plant and Nguyen et al. (2019) ${ }^{[13]}$ for number of pods per plant, plant height, seed yield per plant and harvest index. Days to 50 per cent 
flowering along with days to maturity had low values of GCV and PCV suggesting narrow range of variation for these characters. Findings were in similar trend with Ramesh et al. (2014) ${ }^{[15]}$ for days to 50 per cent flowering and Sable et al. (2018) ${ }^{[16]}$ for days to maturity.

The characters like plant height $(99.80 \%)$, biological yield per plant $(99.10 \%)$, harvest index $(97.60 \%)$, number of pods per plant $(97.20 \%)$, seed yield per plant (96.50\%), 100-seed weight $(92.80 \%)$ and pod length $(89.60 \%)$ depicted high estimates of heritability. These characters can be easily transferred from parent to offsprings. These findings were in conformity with the resultsof Suganthi and Murugan (2008) [22] for seed yield per plant, pod length and 100-seed weight;Sarath and Reshma (2017) ${ }^{\text {[17] }}$ for plant height, seed yield per plant and pod length; Surpura et al. (2017) ${ }^{[23]}$ for number of pods per plant, biological yield per plant, seed yield per plant, 100-seed weight and plant height; Sable et al. (2018) ${ }^{[16]}$ for plant height, seed yield per plant, 100-seed weight, number of pods per plant and harvest index and Gupta et al. (2019) ${ }^{[6]}$ for plant height and number of pods per plant.

Table 1 clearly showed that the number of pods per plant $(101.66 \%)$ followed by harvest index $(86.59 \%)$, seed yield per plant $(81.74 \%)$ and plant height $(70.58 \%)$ had high result values of genetic advance as per cent of mean. Similar outcomes were obtained by Kumar et al. (2018) [10] for number of pods per plant; Khan et al. (2015) ${ }^{[8]}$ and Surpura et al. (2017) ${ }^{[23]}$ for number of pods per plant, plant height and seed yield per plant and Sable et al. (2018) ${ }^{[16]}$ for seed yield per plant, number of pods per plant, harvest index and plant height. Whereas, moderate estimate of genetic advance as per cent of mean were reported for biological yield per plant (51.03\%), 100-seed weight $(42.35 \%)$, number of branches per plant $(36.81 \%)$, number of seeds per pod $(31.41 \%)$ and pod length $(30.12 \%)$.

High heritability and high to moderate genetic advance expressed as per cent of mean were found in plant height, number of pods per plant, harvest index, seed yield per plant, biological yield per plant and 100-seed weight which might be attributed to additive gene effect regulating their expression and phenotypic selection for their amelioration can be brought by simple selection for their genetic improvement over a short span of time. Similar findings were observed by Khan et al. (2015) ${ }^{[8]}$ for plant height, seed yield per plant, 100 -seed weight and number of pods per plant; Sughanthi and Muragan (2008) ${ }^{[22]}$ for seed yield per plant and Surpura et al.

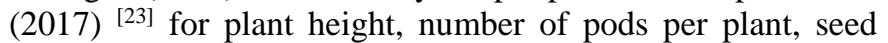
yield per plant, biological yield per plant and 100-seed weight.

The magnitude of genotypic correlation coefficients were higher than phenotypic correlation coefficients for every attribute under the study that indicated inherent interrelation between different characters (Table 2). Thorat and Gadewar (2013) ${ }^{[25]}$, Chattopadhyay et al. (2014) ${ }^{[4]}$, Adetiloye et al. (2017) ${ }^{[1]}$, Tsegaye et al. (2018) ${ }^{[24]}$ and Walle et al. (2018) ${ }^{[26]}$ reported the similar results. Significant and positive phenotypic correlation of seed yield was perceived with harvest index $\left(0.838^{* *}\right)$, number of pods per plant $\left(0.710^{* *}\right)$, number of seeds per pod $\left(0.415^{* *}\right)$, plant height $\left(0.302^{* *}\right)$ and protein content $\left(0.218^{*}\right)$ hinting that these attributes are the primary yield determinant in cowpea. These findings were in accordance with the results of Srinivas et al. (2017) ${ }^{[20]}$; Tsegaye et al. (2018) ${ }^{[24]}$ and Walle et al. (2018) ${ }^{[26]}$.

The phenotypic correlation coefficient of pod length ($0.212 *)$, days to 50 per cent flowering $(-0.328 * *)$ and days to maturity $(-0.259 *)$ was recorded significantly negative with seed yield per plant. The negative correlation of days to 50 per cent flowering and days to maturity with seed yield also suggested that selection for these characters will be of help to the breeders in selecting cultivar for earliness. Similar results were found by Thorat and Gadewar (2013) ${ }^{[25]}$ and Srinivas et al. (2017) ${ }^{[20]}$.

Among the inter relationships, days to maturity possessed significant and positive correlation with days to 50 per cent flowering $\left(0.418^{* *}\right)$ along with 100 -seed weight $\left(0.228^{*}\right)$. Significant and positive correlation was registered by harvest index with number of pods per plant $\left(0.394^{* *}\right)$ and number of seeds per pod $\left(0.310^{* *}\right)$. Similar findings were reported by Walle et al. (2018) ${ }^{[26]}$.

At phenotypic level, the positive direct effect on seed yield per plant was majorly by harvest index (0.9094), biological yield per plant (0.3906), number of pods per plant (0.2089), plant height (0.0604), 100-seed weight $(0.0080)$, number of branches per plant $(0.0058)$, number of seeds per pod $(0.0047)$, protein content $(0.0023)$ and pod length (0.0003) indicating the direct selection for these traits in order to improve seed yield of cowpea whereas, highest negative direct effect were reported for days to 50 per cent flowering ($0.0204)$ and days to maturity (-0.0094). Direct positive effect over seed yield through number of branches per plant, 100seed weight, number of seeds per pod along with number of pods per plant was earlier reported by Meena et al. (2015) ${ }^{[22]}$. Cokkizgin et al. (2013) ${ }^{[5]}$ reported positive direct effect by 100 -seed weight and number of branches per plant. Direct positive effect over seed yield per plant via plant height was earlier reported by Jogdhande et al. (2017) ${ }^{[7]}$, Manisha et al. (2018) ${ }^{[11]}$ and Walle et al. (2018) ${ }^{[26]}$.

Residual effect resulted in path analysis was found to be very low 0.1697 at genotypic level and 0.1820 at phenotypic level representing that there was maximum and sufficient effect of the characters evaluated on seed yield in cowpea.

Therefore, path analysis gave an idea that the characters viz., harvest index, plant height, number of pods per plant and number of seeds per pod possessed high direct positive effect over seed yield with significant and positive relationship and were the major determinants of seed yield.Thus, these traits should be given more emphasis during selection for yield improvement in cowpea.

Table 1: Variability parameters for different characters in cowpea

\begin{tabular}{|c|c|c|c|c|c|c|c|c|c|}
\hline S. No. & Characters & Range & Phenotypic Variance & Genotypic Variance & PCV & GCV & $\mathbf{H}^{2}(\%)$ & GA & GA as \% of mean \\
\hline 1 & Days to 50\% Flowering & $43.00-52.00$ & 4.14 & 3.32 & 4.36 & 3.90 & 80.30 & 3.36 & 7.20 \\
\hline 2 & Days to Maturity & $69.00-74.00$ & 1.74 & 0.74 & 1.88 & 1.23 & 42.60 & 1.16 & 1.65 \\
\hline 3 & Plant Height & $25.65-96.38$ & 497.38 & 496.14 & 34.35 & 34.30 & 99.80 & 45.83 & 70.58 \\
\hline 4 & No. of branches /plant & $1.50-4.30$ & 0.60 & 0.36 & 29.68 & 23.03 & 60.20 & 0.96 & 36.81 \\
\hline 5 & No. of pods/plant & $3.80-22.90$ & 25.63 & 24.92 & 50.76 & 50.05 & 97.20 & 10.14 & 101.66 \\
\hline 6 & No. of seeds/pod & $4.70-10.50$ & 2.34 & 1.77 & 20.09 & 17.50 & 75.90 & 2.39 & 31.41 \\
\hline 7 & Pod length & $10.01-20.36$ & 4.19 & 3.75 & 16.32 & 15.44 & 89.60 & 3.78 & 30.12 \\
\hline 8 & 100-Seed Weight & $8.15-18.34$ & 7.73 & 7.17 & 22.14 & 21.34 & 92.80 & 5.32 & 42.35 \\
\hline
\end{tabular}




\begin{tabular}{|c|c|c|c|c|c|c|c|c|c|}
\hline 9 & Protein Content & $20.63-25.27$ & 1.14 & 0.53 & 4.68 & 3.20 & 46.70 & 1.03 & 4.50 \\
\hline 10 & Biological yield/plant & $23.80-62.40$ & 95.44 & 94.61 & 24.99 & 24.88 & 99.10 & 19.95 & 51.03 \\
\hline 11 & Harvest Index & $4.20-28.55$ & 31.19 & 30.46 & 43.05 & 42.54 & 97.60 & 11.23 & 86.59 \\
\hline 12 & Seed yield/plant & $2.26-10.56$ & 3.97 & 3.83 & 41.13 & 40.40 & 96.50 & 3.96 & 81.74 \\
\hline
\end{tabular}

Table 2: Phenotypic and Genotypic direct (diagonal) and indirect effects (non-diagonal) of different characters

\begin{tabular}{|c|c|c|c|c|c|c|c|c|c|c|c|c|c|}
\hline Characters & & \begin{tabular}{|c|} 
Days to \\
$\mathbf{5 0 \%}$ \\
Flowering \\
\end{tabular} & $\begin{array}{c}\text { Days to } \\
\text { Maturity }\end{array}$ & \begin{tabular}{|c|} 
Plant \\
Height
\end{tabular} & $\begin{array}{c}\text { Number of } \\
\text { branches /plant }\end{array}$ & $\begin{array}{l}\text { Number of } \\
\text { pods /plant }\end{array}$ & $\begin{array}{l}\text { Number of } \\
\text { seeds/pod }\end{array}$ & $\begin{array}{c}\text { Pod } \\
\text { length }\end{array}$ & $\begin{array}{c}\text { 100-Seed } \\
\text { Weight }\end{array}$ & $\begin{array}{l}\text { Protein } \\
\text { Content }\end{array}$ & \begin{tabular}{|c|} 
Biological \\
yield/ \\
plant
\end{tabular} & $\begin{array}{l}\text { Harvest } \\
\text { Index }\end{array}$ & $\begin{array}{l}\text { Seed } \\
\text { yield } \\
\text { /plant }\end{array}$ \\
\hline \multirow{2}{*}{$\begin{array}{c}\text { Days to } 50 \% \\
\text { Flowering }\end{array}$} & $\mathrm{P}$ & \begin{tabular}{|l|}
-0.0204 \\
\end{tabular} & $\begin{array}{l}-0.0039 \\
\end{array}$ & \begin{tabular}{|l|}
-0.0104 \\
\end{tabular} & 0.0011 & -0.0935 & -0.0014 & \begin{tabular}{|l|}
0.0000 \\
\end{tabular} & 0.0031 & -0.0003 & -0.0200 & -0.1832 & 0.3289 ** \\
\hline & $\mathrm{G}$ & -0.0001 & -0.0370 & -0.0157 & 0.0078 & -0.1164 & -0.0044 & $\begin{array}{c}- \\
0.0001 \\
\end{array}$ & 0.0132 & 0.0010 & -0.0187 & -0.1790 & -0.3494 \\
\hline \multirow{2}{*}{$\begin{array}{l}\text { Days to } \\
\text { Maturity }\end{array}$} & $\mathrm{P}$ & -0.0085 & 0094 & 0101 & 7 & 0147 & 7 & \begin{tabular}{|l|}
0.0000 \\
\end{tabular} & 0018 & .0001 & -0.0369 & 1826 & $-0.2595 *$ \\
\hline & $\mathrm{G}$ & -0.0001 & -0.0515 & -0.0215 & 0.0158 & -0.0215 & -0.0043 & $0 . \overline{-}$ & 0.0121 & 0.0011 & -0.0569 & -0.2702 & -0.3972 \\
\hline \multirow[t]{2}{*}{ Plant Height } & $\mathrm{P}$ & 0.0035 & 0.0016 & 0.0604 & -( & 0 & 0 & $\begin{array}{c}- \\
0.0001 \\
\end{array}$ & 5 & 2 & 0.0791 & 0.1189 & $0.3021 * *$ \\
\hline & $\mathrm{G}$ & 0.0000 & 0.0314 & 0.0826 & 00206 & 0.0505 & 00009 & 0.0003 & -0.0056 & -0.0007 & 0.0718 & 0.1138 & 0.3065 \\
\hline \multirow{2}{*}{\begin{tabular}{|c|} 
Number of \\
branches/pla \\
nt \\
\end{tabular}} & $\mathrm{P}$ & -0.0038 & -0.0027 & \begin{tabular}{|l|}
-0.0275 \\
\end{tabular} & 0 & ( & -0.0003 & 0.0001 & 0.0008 & 0.0001 & 0.0449 & 1423 & -0.0867 \\
\hline & G & 0.0000 & -0.0231 & -0.0485 & 0.0351 & 0.0597 & -0.0001 & \begin{tabular}{|c|}
- \\
0.0003 \\
\end{tabular} & 0.0025 & 0.0011 & 0.0519 & -0.1631 & -0.0848 \\
\hline \multirow{2}{*}{$\begin{array}{l}\text { Number of } \\
\text { pods/plant }\end{array}$} & $\mathrm{P}$ & 0.0091 & 0.0007 & 0.0123 & 0.0011 & 0.2089 & 0.0022 & $\begin{array}{c}- \\
0.0001\end{array}$ & 029 & 0.0007 & 0.1203 & 38 & $*$ \\
\hline & $\mathrm{G}$ & 0.0000 & 0.0045 & 170 & 0. & 460 & 0 & 0.0002 & & 26 & 104 & 68 & 0.7267 \\
\hline \multirow{2}{*}{$\begin{array}{c}\text { Number of } \\
\text { seeds/pod }\end{array}$} & $\mathrm{P}$ & 0.0060 & 0015 & 0.0035 & 1 & 5 & 0.0047 & 0.0000 & -0.0023 & 0.0004 & 0.0229 & 0.2821 & $0.4150 * *$ \\
\hline & $\mathrm{G}$ & 0.0000 & 0153 & 0.0052 & 002 & 295 & 0.0 & 0.0001 & -0.0110 & -0.0024 & 0.0239 & .3095 & 0.4846 \\
\hline \multirow[b]{2}{*}{ Pod length } & $\mathrm{P}$ & -0.0020 & -0.0011 & -0.0238 & 0 . & -0.0588 & -0.0003 & 0.0003 & 0.0024 & -0.0001 & -0.2013 & 0.0710 & $-0.2122 *$ \\
\hline & $\mathrm{G}$ & 0.0000 & -0.0120 & -0.0344 & 0.0123 & -0.0732 & -0.0025 & $\begin{array}{c}- \\
0.0008\end{array}$ & 0.0095 & 0.0000 & -0.1923 & 0.0810 & -0.2124 \\
\hline \multirow{2}{*}{$\begin{array}{l}\text { 100-Seed } \\
\text { Weight }\end{array}$} & $\mathrm{P}$ & -0.0079 & -0.0021 & -0.0110 & 0.0006 & -0.0751 & -0.0013 & \begin{tabular}{|l|}
0.0001 \\
\end{tabular} & 0.0080 & 0.0006 & -0.1382 & 0.0413 & -0.1851 \\
\hline & G & 0.0000 & -0.0206 & -0.0153 & 0.0029 & -0.0959 & -0.0053 & 0.0003 & 0.0303 & -0.0023 & -0.1299 & 0.0399 & -0.1965 \\
\hline \multirow{2}{*}{$\begin{array}{l}\text { Protein } \\
\text { Content }\end{array}$} & $\mathrm{P}$ & 0.0028 & 0.0005 & 0.0052 & 0.0002 & 0.0601 & 0.0008 & 0.0000 & 0.0021 & 0.0023 & -0.0521 & 0.1970 & $0.2188^{*}$ \\
\hline & $\mathrm{G}$ & 0.0000 & 0.0095 & 0.0099 & -0.0063 & 0.1058 & 0.0058 & 0.0000 & 0.0117 & -0.0060 & -0.0684 & 0.2684 & 0.3305 \\
\hline \multirow{2}{*}{$\begin{array}{l}\text { Biological } \\
\text { yield/plant }\end{array}$} & $\mathrm{P}$ & 0.0010 & 0.0009 & 0.0122 & 0.0007 & 0.0643 & 0.0003 & $\begin{array}{c}- \\
0.0001\end{array}$ & -0.0028 & -0.0003 & 0.3906 & -0.3939 & 0.0728 \\
\hline & $\mathrm{G}$ & 0.0000 & 083 & \begin{tabular}{|l|}
0.0168 \\
\end{tabular} & 0 & 0.0769 & 0.0010 & 0.0004 & -0.0111 & 0.0012 & 0.3534 & $\begin{array}{l}-0.3822 \\
\end{array}$ & 0.0698 \\
\hline \multirow{2}{*}{$\begin{array}{l}\text { Harvest } \\
\text { Index }\end{array}$} & $\mathrm{P}$ & 0.0041 & 0.0019 & 0.0079 & -0.0009 & 0.0824 & 0.0015 & \begin{tabular}{|l|}
0.0000 \\
\end{tabular} & 0.0004 & 0.0005 & -0.1691 & 0.9094 & $0.8380 * *$ \\
\hline & G & 0.0000 & 0.0160 & 0.0108 & -0.0066 & 0.0983 & 0.0052 & 0.0001 & 0.0014 & -0.0018 & -0.1556 & 0.8681 & 0.8359 \\
\hline $\mathrm{P}$ & \\
\hline G & & & & & & & & & & & & & \\
\hline
\end{tabular}

\section{References}

1. Adetiloye IS, Ariyo OJ, Awoyomi OL. Study of Genotypic and Phenotypic Correlation among 20 Accessions of Nigerian Cowpea. J Agriculture and Veterinary Science, 2017; 10:36-39.

2. Animasaun DA, Oyedeji S, Azeez YK, Mustapha OT, Azeez MA. Genetic variability study among ten cultivars of cowpea [Vigna unguiculata (L.) Walp.] using morphoagronomic traits and nutritional composition. The $\mathbf{J}$ Agricultural Sci. 2015; 10(2):119-130.

3. Burton GW. Quantitative inheritance in grasses. Proc. Sixth Int. Grassland Cong. 1952, 277-285.

4. Chattopadhyay A, Rana NP, Seth T, Das S, Chatterjee S, Dutta S. Identification of selection indices and choosing of parents for vegetable cowpea (Vignaunguiculatacv-gr. sesquipedalis) breeding programme. Legume Research, 2014; 37(1):19-25.

5. Cokkizgin A, Colkesen M, Idikut L, Ozsisli B, Girgel U. Determination of relationship between yield components in bean by using path coefficient analysis. Greener $\mathbf{J}$ Agri. Sci. 2013; 3(2):85-89.

6. Gupta RP, Arya M, Kumar A, Kumari P. Study on genetic variability in cowpea [Vigna unguiculata (L.) Walp.]. Curr. J App. Sci. and Tech. 2019; 33(2):1-8.

7. Jogdhande Srinivas, Vijay S Kale, Nagre PK. Correlation and Path Analysis Study in Cowpea [Vigna unguiculata (L.) Walp.] Genotypes. Int. J Curr. Microbiol. App. Sci. 2017; 6(6):3305-3313.
8. Khan H, Viswanatha KP, Sowmya HC. Study of genetic variability parameters in cowpea [Vigna unguiculata (L.) Walp.] germplasm lines. National Environmentalists Asso., Jharkhand, India. 2015; 10(2):747-750.

9. Kouam EB, Ngompe-Deffo T, Anoumaa M, Pasquet RM. Preliminary study on character associations, phenotypic and genotypic divergence for yield and related quanitative traits among cowpea landraces [Vigna unguiculata] from the Western Highland Region of Cameroon. Open Agriculture. 2018; 3:84-97.

10. Kumar S, Patel PS, Kumar P. Genetic variability, heritability and genetic advance in cowpea [Vigna unguiculata (L.) Walp.]. Plant Archives. 2018; 18(2):1268-1270.

11. Manisha RP, Vijay SK, Madhavi BB, Jadhav RD. Correlation and Path Analysis Study in F5 Generation of Cowpea. Int. J. Cur. Microbio. App. Sci., 2018; 6:15291537.

12. Meena HK, Ram Krishna K, Singh B. Character associations between seed yield and its components traits in cowpea [Vignaunguiculata (L.) Walp.]. Indian J Agriculture Res., 2015; 49(6):567-570.

13. Nguyen NV, Arya RK, Panchta Ravish. Studies on genetic parameters, correlation and path coefficient analysis in cowpea. Range Mng. and Agroforestry. 2019; 40(1):49-58.

14. Patel UV, Parmar VK, Patel AI. Genetic variability and heritability studies in cowpea [Vigna unguiculata (L.) 
Walp.]. J Adv. in Life Sci. Navsari Agric. Uni., 2018; 5(19). ISSN 2278-3849.

15. Ramesh P, Nautiyal MK, Singh YV, Sharma CL. Evaluation of genetic variability for some of quantitative traits in grain cowpea [Vigna unguiculata (L.) Walp.]. Int. J Basic and Applied Agri. Res. 2014; 12(2):188-192.

16. Sable GR, Bhave SG, Desai SS, Dalvi MB, Pawar PR. Variability and genetic advance studies in F2 generation of cowpea [Vigna unguiculata (L.) Walp.]. Int. J Curr. Microbiol. App. Sci. 2018; 7(9):3314-3320.

17. Sarath PS, Reshma T. Genetic variability studies in cowpea [Vignaunguiculata (L.) Walp.]. Int. J Agricultural Sci. and Res. 2017; 7(3):129-132.

18. Searle SR. Phenotypic, genotypic and environmental correlations. Biometrics. 1961; 17:474-480.

19. Singh OV, Shekhawat N, Singh K, Gowthami R. Genetic divergence studies in cowpea [Vignaunguiculata (L.) Walp.] germplasm using Mahalanobis $\mathrm{D}^{2}$ analysis. Int. J Curr. Microbiol. and App. Sci., 2018; 7(3):2616-2624.

20. Srinivas J, Kale VS, Nagre PK. Correlation and path analysis study in cowpea [Vigna unguiculata (L.) Walp.] genotypes. Int. J Curr. Microbiol. App. Sci. 2017; 6(6):3305-3313.

21. Stanton WR. Grain legumes in Africa. Food and agricultural organisation of the United Nations, Rome, Italy, 1966, 210-213.

22. Suganthi S, Murugan S. Association analysis in cowpea [Vignaunguiculata (L.) Walp.]. Legume Res., 2008; 31(2):130-132.

23. Surpura MH, Sharma SC. Genetic variability for yield and physiological traits in cowpea [Vigna unguiculata (L.) Walp.]. The Allahabad Farmer, 2017; 19(3):401-475.

24. Tsegaye D, Mohammed H, Amsalu H. Correlation and path coefficient analysis of yield and yield related traits interactions in Ethiopian cowpea [Vigna unguiculata (L.) Walp.] accessions. Aca. Res. J of Agri. Sci. and Res. 2018; 6(9):526-530.

25. Thorat A, Gadewar RD. Variability and correlation studies in cowpea [Vignaunguiculata (L.) Walp.]. International J. Environmental Rehabilitation and Conservation. 2013; 4(1):44-49.

26. Walle T, Mekbib F, Amsalu B, Gedil M. Correlation and path coefficient analyses of cowpea [Vignaunguiculata (L.)] landraces in Ethiopia. American J Pl. Sci. 2018; 9:2794-2812.

27. Wright S. Correlation and causation. J Agricultural Res. $1921 ; 20: 257-287$. 